Jurnal Keperawatan I CARE, Vol. 2 No. 2 Tahun 2021

\title{
HUBUNGAN ANTARA PERILAKU CARING PERAWAT TERHADAP KEPUASAN PASIEN SAAT PANDEMI COVID-19 DI RUANG PERAWATAN SALAH SATU RUMAH SAKIT SWASTA DI YOGYAKARTA
}

\author{
Martina Dyah Lestari ${ }^{1}$, Agustina Sri Oktri Hastuti, M. Kep., PhD NS ${ }^{2}$ Sr. \\ Therese Maura Harjanti CB, $\mathrm{MSN}^{3}$ \\ ${ }^{1}$ STIKes Panti Rapih Yogyakarta, Jl. Tantular No 401, Condongcatur, Depok, \\ Sleman,Yogyakarta, email: mdyahlestari@gmail.com \\ ${ }^{1}$ STIKes Panti Rapih Yogyakarta, Jl. Tantular No 401, Condongcatur, Depok, \\ Sleman,Yogyakarta, email: oktri_hastuti@stikespantirapih.ac.id \\ ${ }^{1}$ STIKes Panti Rapih Yogyakarta, Jl. Tantular No 401, Condongcatur, Depok, \\ Sleman, Yogyakarta, email: maura_hardjanti@stikespantirapih.ac.id
}

\begin{abstract}
ABSTRAK
Latar belakang: Kepuasan pelayanan keperawatan didapatkan dari penilaian konsumen terkait mutu dan kinerja terhadap manfaat yang diterima dari produk atau jasa layanan. Pelayanan keperawatan yang berkualitas dapat diwujudkan melalui pemberian asuhan keperawatan dengan didasari oleh perilaku caring perawat. Perilaku caring harus selalu dilakukan perawat disegala kondisi, bahkan saat situasi pandemi COVID-19 saat ini. Dalam studi pendahuluan yang dilakukan, ruang rawat inap Elisabeth 4 adalah ruangan yang mengalami penurunan angka kepuasanan pelanggan yang terendah.
\end{abstract}

Tujuan: Tujuan dari penelitian ini adalah untuk mengetahui hubungan antara perilaku caring perawat terhadap kepuasan pasien di masa pandemi COVID-19 di ruang rawat inap Elisabeth 4 RS. Panti Rapih, Yogyakarta.

Metode: Jenis penelitian ini adalah deskriptif korelasi. Penelitian ini merupakan penelitian kuantitatif dengan desain Cross Sectional. Menggunakan teknik non probability sample, purposive sample. sampel yang digunakan sejumlah 37 responden. Teknik pengumpulan data menggunakan kuisioner yang diberikan secara langsung pada responden pada bulan Januari 2021 sampai Februari 2021. 
Hasil: Perilaku caring perawat paling tinggi adalah kategori baik $83,8 \%$ dari jumlah responden. Tingkat kepuasan paling tinggi adalah "Puas" 54,1\% dari jumlah responden dan "Sangat Puas" sebanyak 43,2\% dari jumlah responden. Berdasarkan hasil uji spearman rho didapatkan $\mathrm{P}$ value 0,007, artinya ada hubungan yang signifikan antara perilaku caring perawat dengan tingkat kepuasan pasien. Nilai correlation coefficient positif, menunjukkan terdapat hubungan yang kuat antara perilaku caring perawat dengan kepuasan pasien.

Simpulan: Terdapat hubungan yang signifikan antara perilaku caring perawat dengan tingkat kepuasan pasien. Arah korelasi positif menunjukkan bahwa semakin tinggi perilaku caring perawat, maka kepuasan pasien pada pelayanan keperawatan juga akan semakin tinggi.

Saran: Perawat disarankan untuk meningkatkan pengetahuan, sikap dan khususnya keterampilan ketika menjalankan perannya sebagai pelaksana tindakan keperawatan profesional. Kepada pihak manajemen RS. Panti Rapih untuk terus mendukung semangat caring para perawat dimasa pandemi COVID-19 ini, dengan cara meningkatkan kesehatan fisik, mental dan spiritual perawat sehingga perawat dapat memberikan pelayanan keperawatan dengan professional.

Kata kunci: Caring, COVID-19, kepuasan,

\begin{abstract}
ABSTRCT
Background: Patient satisfaction is one of the factors used to evaluate the quality of service in the hospital, and is one of the factors determining the image of a health service institution. Nursing service satisfaction is obtained from consumer assessments regarding the quality and performance of the benefits received from products or services. Quality nursing services can be realized through the provision of nursing care based on the caring behavior of nurses. Caring behavior must always be carried out by nurses in all conditions, even during the current COVID-19 pandemic situation. In the preliminary study conducted, Elisabeth 4's inpatient room was the room that experienced the lowest decrease in customer satisfaction.
\end{abstract}

Purpose: The purpose of this study was to determine the relationship between nurse caring behavior and patient satisfaction during the COVID-19 pandemic in Elisabeth 4 Hospital's inpatient room. Panti Rapih, Yogyakarta. 
Jurnal Keperawatan I CARE, Vol. 2 No. 2 Tahun 2021

Methods: This type of research is a descriptive correlation. This research is a quantitative study with a cross sectional design. Using non probability sample techniques, purposive sample. The sample used was 37 respondents. Data collection techniques using a questionnaire that is given directly to the respondent in Januari 2021 sampai Februari 2021.

Results: The highest nurse caring behavior was in the good category, $83.8 \%$ of the total respondents. The highest level of satisfaction is "Satisfied" $54.1 \%$ of the total respondents and "Very Satisfied" as much as $43.2 \%$ of the total respondents. Based on the results of the Spearman rho test, $\mathrm{P}$ value 0.007 is, this means that there is a significant relationship between nurse caring behavior and the level of patient satisfaction. The Correlation Coefficient value is positive, which indicates that there is a strong relationship between nurse caring behavior and the level of patient satisfaction.

Conclusion: There is a significant relationship between nurse caring behavior and patient satisfaction. The direction of the positive correlation shows that the higher the nurse's caring behavior, the higher the patient's satisfaction in nursing services.

Suggestion: It is necessary for nurses to increase knowledge, attitudes and skills especially when carrying out their role as executor of professional nursing actions.

Panti Rapih Hospital management should continue to encourage the spirit of caring behaviour during the COVID-19 pandemic, by improving the physical, mental and spiritual health of nurses so that nurses can provide professional nursing services.

Key word's: Caring, COVID-19, satisfaction,

\section{PENDAHULUAN}

Kepuasan pasien merupakan salah satu faktor yang digunakan untuk mengevaluasi mutu pelayanan di rumah sakit, dan menjadi salah satu faktor penentu citra institusi pelayanan kesehatan (Depkes RI, 2008). Definisi kepuasan pasien menurut Pohan (2013) adalah, suatu tingkat perasaan pasien yang timbul sebagai akibat dari kinerja layanan kesehatan yang diperoleh pasien setelah pasien membandingkan dengan apa yang menjadi harapannya. Pasien yang mengalami kepuasan terhadap layanan kesehatan merupakan aset yang berharga bagi rumah sakit, karena pasien tersebut akan terus memakai jasa Rumah Sakit tersebut. 
Martina Dyah Lestari, Agustina Sri Oktri Hastuti, M. Kep., PhD NS,

Sr. Therese Maura Harjanti CB, MSN

Hubungan Antara Perilaku Caring Perawat Terhadap Kepuasan Pasien Saat Pandemi Covid-19 di Ruang Perawatan Salah Satu Rumah Sakit Swasta di Yogyakarta

Pohan (2013) juga mengungkapkan kebalikannya, bahwa pasien yang merasa tidak puas dan kecewa terhadap layanan kesehatan akan cenderung tidak mematuhi rencana pengobatan, tidak mematuhi nasehat dan bahkan berganti dokter atau pindah ke fasilitas kesehatan yang lain. Selain itu, apabila pasien tidak puas, ada kemungkinan besar mereka akan memberitahukan ketidakpuasan mereka pada orang lain. Hal itu tentu akan sangat merugikan rumah sakit terutama dalam hal tingkat kepercayaan dari masyarakat (Umam, Muchlison, \& Maryati, 2019). Pelayanan keperawatan yang berkualitas dapat diwujudkan melalui pemberian asuhan keperawatan dengan didasari oleh perilaku caring perawat.

Caring merupakan sentral dari keperawatan. Perilaku caring adalah suatu tindakan yang didasari oleh kepedulian, kasih sayang, keterampilan, empati, tanggung jawab, sensitif, dan dukungan. Perilaku ini berfungsi untuk memperbaiki atau meningkatkan kondisi dan cara hidup manusia yang menekankan pada aktivitas yang sehat dan memampukan individu serta kelompok berdasarkan budaya (Watson, 1979, dalam Kusnanto, 2019). Perilaku caring perawat sangat penting dalam memenuhi kepuasan pasien. Caring merupakan suatu cara pendekatan yang dinamis, di mana perawat bekerja untuk lebih meningkatkan kepeduliannya terhadap pasien.

Perawat adalah orang yang menjadi salah satu kunci dalam memenuhi kepuasan pasien. Oleh karena itu, perilaku caring perawat dapat memberikan pengaruh dalam pelayanan yang berkualitas kepada pasien (Prompahakul et.al, 2011). Hal ini sejalan dengan penelitian yang dilakukan oleh Gurusinaga dkk (2013) di Rumah Sakit Grand Medistra Lubuk Pakamya yang menyimpulkan bahwa ada korelasi antara perilaku caring perawat dengan kepuasan pasien rawat inap. Perilaku caring harus selalu dilakukan perawat disegala kondisi, bahkan saat situasi pandemi COVID-19 saat ini.

Corona virus 19 (COVID-19) telah dinyatakan sebagai pandemi dunia oleh WHO (WHO, 2020). Corona virus adalah zoonosis atau virus yang ditularkan antara hewan dan manusia. Virus dan penyakit ini diketahui berawal di kota Wuhan, Cina sejak Desember 2019. Pertanggal 21 Maret 
Jurnal Keperawatan I CARE, Vol. 2 No. 2 Tahun 2021

2020, jumlah kasus penyakit ini mencapai angka 275,469 jiwa yang tersebar di 166 negara. Jumlah kasus COVID-19 terus meningkat di berbagai belahan dunia, termasuk Indonesia (Yustisia, Utama, Aprilatutini, 2020). Presiden Republik Indonesia telah menyatakan status penyakit ini menjadi tahap Tanggap Darurat pada tanggal 17 Maret 2020. Indonesia sendiri pada Jumat 13/11/2020, dalam peta persebaran COVID-19 milik BNPB, sebanyak 457.735 kasus terkonfirmasi dengan 15.037 orang meninggal dan 385.094 orang dinyatakan sembuh (BNPB, November 2020). Di RS. Panti Rapih sendiri didapatkan data pasien konfirmasi COVID-19 sebanyak 39 pasien, Konfirmasi COVID-19 meninggal 10 pasien, Konfirmasi COVID-19 sembuh 75 pasien (Rekam Medis Rumah Sakit Panti Rapih, 2020).

Berdasarkan studi epidemiologi dan virologi saat ini membuktikan bahwa COVID-19 utamanya ditularkan dari orang yang bergejala (simptomatik) ke orang lain droplet. Strategi PPI untuk mencegah atau memutuskan rantai penularan infeksi COVID-19 di fasilitas pelayanan kesehatan dapat dicapai dengan penerapan prinsip pencegahan

dan pengendalian risiko penularan COVID-19, yaitu kewaspadaan standart berupa hand hygiene, etika batuk, penggunaan APD. Selain itu diperlukan pengendalian administratif yaitu penerapan jaga jarak minimal 1 meter.

Proses penularan COVID-19 yang cepat dan dapat berakibat kematian, dapat menjadi pemicu menurunnya perilaku caring perawat, yang sangat penting untuk meningkatkan mutu pelayanan. Hal tersebut dapat disebabkan karena perawat mengalami kecemasan, ketakutan tertular dan terinfeksi Covid19. Dalam studi pendahuluan yang dilakukan, didapatkan data rata-rata angka kepuasan pasien selama masa pandemi COVID-19 di salah satu ruang rawat inap salah satu rumah sakit swasta di Yogyakarta adalah 95\%. Dari keseluruhan ruang rawat inap, ruang "E" adalah ruangan yang mengalami penurunan angka kepuasanan pelanggan selama 2 bulan berturut-turut yaitu bulan September $(94,1 \%)$ dan Oktober (94,2\%). Angka kepuasan tersebut merupakan yang terendah.

Menurut pengamatan peneliti, terjadi beberapa perubahan perilaku perawat di ruang rawat inap " $E$ ". 
Martina Dyah Lestari, Agustina Sri Oktri Hastuti, M. Kep., PhD NS,

Sr. Therese Maura Harjanti CB, MSN

Hubungan Antara Perilaku Caring Perawat Terhadap Kepuasan Pasien Saat Pandemi Covid-19 di Ruang Perawatan Salah Satu Rumah Sakit Swasta di Yogyakarta

Sebelum masa pandemi, masker digunakan sangat ketat oleh perawat pada pasien dengan penyakit yang menular melalui airbone atau dlopret seperti TBC yang dirawat di ruang isolasi. Tetapi di masa pandemi COVID 19 ini, selain karena protokol kesehatan, pemakaian masker pada semua pasien, juga disebabkan karena kewaspadaan perawat bahwa pasien yang dihadapi mungkin mengalami infeksi COVID 19. Selain khawatir terinfeksi, dari percakapan yang dilakukan peneliti dengan beberapa perawat, kekhawatiran penularan ke anggota keluarga, dan stigma tentang pekerjaan perawat juga menjadi beban psikologi bagi perawat. Perawat di ruang rawat inap tersebut hadir seminimal mungkin pada pasien, menjaga jarak dengan pasien, mengurangi kontak dan sentuhan dengan pasien, sebisa mungkin melibatkan keluarga untuk memenuhi kebutuhan pasien. Berbicara seperlunya, sehingga dapat mengakibatkan perawat kurang memahami kebutuhan pasien. Hal tersebut jika dilakukan terus menerus, dapat mengakibatkan ketidakpuasan pada pasien, mengingat pandemi COVID-19 belum dapat dipastikan kapan akan berakhir. Ketidak puasan pasien dapat berpengaruh pada citra Rumah Sakit. Berdasarkan latar belakang tersebut, penulis melakukan penelitian tentang perilaku caring perawat ruang rawat inap di salah satu rumah sakit swasta di Yogyakarta sesuai teori caring Jean Watson.

\section{METODE PENELITIAN}

Jenis penelitian ini adalah deskriptif korelasi untuk mengetahui hubungan antara perilaku caring perawat dengan kepuasan pasien di salah satu ruang rawat inap Rumah Sakit Swasta di Yogyakarta. Penelitian ini merupakan penelitian kuantitatif dengan desain cross sectional. Populasi dari penelitian ini adalah 41 orang. Sampel dalam penelitian ini yaitu sejumlah 37 pasien. Diambil dengan teknik non probability sample, purposive sample dengan kriteria inklusi adalah seluruh pasien rawat inap dewasa (umur di atas 17 tahun) yang telah menjalani perawatan di ruang rawat inap rumah sakit selama 3 hari atau lebih, yang sadar penuh, dan mampu memberikan penilaian secara pribadi tentang perilaku caring perawat. Instrumen penelitian menggunakan kuisioner yang telah dilakukan uji 
Jurnal Keperawatan I CARE, Vol. 2 No. 2 Tahun 2021

validitas dan realibilitas. Analisa bivariat menggunaka uji korelasi Spearman Rho dengan tingkat kemaknaan $P$ value 0,05 , dan tingkat kepercayaan $95 \%$.

\section{HASIL DAN PEMBAHASAN}

Tabel 1

Karakteristik Usia Responden

Januari-Februari 2021 $(\mathrm{n}=37)$

\begin{tabular}{ccc}
\hline Kategori & Frekuensi & Presentase \\
\hline $25-40$ & 4 & 24.3 \\
$41-55$ & 6 & 35.1 \\
$56-70$ & 8 & 29.7 \\
$71-85$ & 13 & 10.8 \\
\hline Total & 37 & 100.0 \\
\hline
\end{tabular}

Sumber: Data Primer, 2021

Berdasarkan data diatas, usia responden dalam penelitian paling banyak adalah kelompok umur dewasa akhir sampai lansia. Hal ini karena ruang rawat inap "E" merupakan bangsal penyakit dalam, dimana penyakit yang diderita pasien paling banyak adalah penyakit kronis, maupun degenerative. Penyakit degeneratif adalah penyakit yang diakibatkan oleh terjadinya penurunan fungsi organ tubuh dan umumnya terjadi pada usia lanjut (Amelia, 2010 dalam Lusiana et.al, 2019). Hasil penelitian ini sesuai dengan pernnyataan Susenas (2012, dalam Misnaniarti, 2017) bahwa

proporsi penduduk lansia yang sakit yang berobat jalan ke Rumah Sakit (pemerintah/swasta) dan praktik dokter lebih tinggi pada daerah perkotaan dibanding pedesaan.

Tabel 2

Karakteristik Jenis Kelamin Responden Januari-Februari 2021 $(n=37)$

\begin{tabular}{ccc}
\hline Kategori & Frekuensi & Presentase \\
Laki-laki & 17 & 45.9 \\
Perempuan & 20 & 54.1 \\
Total & 37 & 100.0 \\
\hline
\end{tabular}

Sumber: Data primer 2021

Berdasarkan data diatas didapatkan jumlah jenis kelamin responden perempuan lebih banyak dari laki-laki. Menurut Addani (2008, dalam Nugrahaheni, 2019) Angka morbiditas perempuan lebih tinggi dan lebih mudah merasakan sakit dibandingkan laki-laki, dan sering mengalami keluhan kualitas hidup seperti nyeri sendi, sakit kepala, sehingga pelayanan kesehatan mayoritas pasiennya adalah perempuan. Menurut peneliti jenis kelamin perempuan lebih banyak, karena faktor hormonal dan metabolisme, terutama saat memasuki masa lansia. Hal ini sesuai dengan data penelitian di karakteristik umur responden, yang sebagian besar memasuki masa dewasa akhir sampai lansia. Hasil penelitian ini sejalan dengan penelitian yang dilakukan oleh 
Martina Dyah Lestari, Agustina Sri Oktri Hastuti, M. Kep., PhD NS,

Sr. Therese Maura Harjanti CB, MSN

Hubungan Antara Perilaku Caring Perawat Terhadap Kepuasan Pasien Saat Pandemi Covid-19 di Ruang Perawatan Salah Satu Rumah Sakit Swasta di Yogyakarta

Indrayani dan Ronoatmodjo (2018). Hasil analisis bivariat menunjukkan bahwa ada hubungan antara jenis kelamin dengan kualitas hidup lansia ( $p$ value $<0,05)$. Hal ini berkaitan dengan lansia perempuan mengalami keluhan sakit baik akut maupun kronis lebih tinggi dibandingkan dengan lansia lakilaki, keluhan ini berpengaruh terhadap kualitas hidup lansia.

\section{Tabel 3}

Karakteristik Pendidikan Responden

\begin{tabular}{|c|c|c|}
\hline Kategori & Frekuensi & Presentase \\
\hline SD & 2 & 5.4 \\
\hline SM & 6 & 16.2 \\
\hline SMA & 14 & 37.8 \\
\hline DIII & 6 & 16.2 \\
\hline $\mathrm{S} 1$ & 9 & 24.3 \\
\hline Total & 37 & 100.0 \\
\hline
\end{tabular}

Sumber: Data primer, 2021

Berdasarakan tabel diatas, tingkat pendidikan responden yang paling banyak adalah pendidikan dasar yaitu 59,4\%. sebagian besar lulusan SMA dan paling sedikit adalah lulusan SD. Hal ini disebabkan oleh karena pasien yang menjalani rawat inap adalah pasien dengan status ekonomi menengah kebawah, karena sebagian besar ruang rawat inap yang digunakan untuk penelitian adalah kelas $2(41,4 \%)$ dan kelas $3(21,9 \%)$, sehingga biaya perawatan masih dapat dijangkau oleh pasien. Sesuai dengan penelitian
Ramdan, et.al (2019) bahwa faktor tidak adanya biaya menjadi penyebab yang paling signifikan untuk mempengaruhi minat lanjutan studi.

\section{Tabel 4}

Karakteristik Pendidikan Responden

\begin{tabular}{ccc}
\multicolumn{3}{c}{ Januari - Februari $2021(\mathrm{n}=37)$} \\
\hline Kategori & Frekuensi & Presentase \\
\hline Biarawati & 1 & 2.7 \\
IRT & 6 & 16.2 \\
Lain-lain & 11 & 29.7 \\
Pensiunan & 3 & 8.1 \\
PNS & 1 & 2.7 \\
Swasta & 15 & 40.5 \\
\hline Total & 37 & 100.0
\end{tabular}

Sumber: Data primer, 2021

Dari tabel diatas, pekerjaan responden paling banyak yaitu swasta sebanyak 40,5 \% dan lain-lain 29,7\%. Pekerjaan lain-lain adalah buruh, petani dan tidak bekerja. Hal ini sesuai dengan analisa dari tingkat pendidikan pasien, yang menunjukkan tingkat ekonomi pasien di ruang inap tempat dilakukannya penelitian. Berdasarkan penelitian yang dilakukan oleh Astuti (2017) yang berjudul "Hubungan Faktor Usia, Jenis Kelamin, Pekerjaan dengan Jenis Stroke", didapatkan Stroke terjasi pada $53(42,1 \%)$ pasien bekerja tidak tetap. Penelitian tersebut juga mendapatkan hasil bahwa Stroke juga terjadi pada $25(19,8 \%)$ orang yang tidak bekerja. Menurut Soetjipto (2006 dalam Astuti, 2017) hal ini dikarenakan 
Jurnal Keperawatan I CARE, Vol. 2 No. 2 Tahun 2021

adanya kecenderungan hidup santai, pola makan yang tidak benar, malas berolahragadan tingkat steress yang lebih tinggi dibandingkan denganorang yang bekerja. Faktor-faktpr inilah yang mengakibatkan kurangnya kemampuan metabolisme dalam proses pembakaran zat-zat makanan yang dikonsumsi. Sehingga inid apat beresiko terjadinya tumpukan kdar lemak dan kolesterol dalam darah yang beresiko membentuk aterosklerosis yangd apat menyumbat pembuluh darah yang dapat berakibat munculnya stroke.

Tabel 5

Perilaku Caring Perawat

Di Ruang Rawat Inap Salah Satu RS Januari-Februari 2021 $(n=37)$

\begin{tabular}{ccc}
\hline Kategori & Frekuensi & Presentase \\
\hline Kurang & 0 & 0 \\
Cukup & 6 & 16.2 \\
Baik & 31 & 83.8 \\
\hline Total & 37 & 100.0 \\
\hline
\end{tabular}

Sumber: data primer

Setelah dilakukan penelitian mengenai perilaku caring perawat dan kepuasan pasien rawat inap diperoleh hasil bahwa perilaku caring perawat kategori baik yaitu 31 orang, 83,8\% dari jumlah responden dan perilaku caring perawat kategori cukup sebanyak 6 orang, 16,2\% dari jumlah responden (Tabel 4.5). Hal tersebut menunjukkan bahwa menurut sebagian besar pasien yang dirawat di ruang rawat inap, di masa pandemi ini, perawat tetap mampu menunjukkan perilaku caring sesuai yang diharapkan. Keterbatasan sentuhan fisik yang disebabkan oleh protokol kesehatan yang harus ditaati, seperti penggunaan Alat Pelindung Diri (APD) lengkap (masker, sarung tangan, faceshield) saat berinteraksi dengan pasien, tidak mempengaruhi perilaku caring pasien. Hal ini karena perilaku caring perawat tetap dapat ditampilkan dan dirasakan oleh pasien melalui cara berkomunikasi perawat, bertanggung jawab dalam memenuhi kebutuhan pasien secara berhati-hati, dan tetap menunjukkan bahasa tubuh yang bersahabat. Perawat tetap memberikan motivasi pada pasien saat merawat pasien, seperti mengingatkan untuk selalu bersikap tenang, jangan stres, berpikir positif, selalu berdoa dan bersyukur. Memberikan semangat untuk sembuh, Perawat memberikan edukasi mengajak pasien untuk semangat. Perawat menunjukkan sikap empatinya terhadap klien dan keluarga, ikut merasakan apa yang dirasakan oleh pasien. Rasa empati ditunjukkan dengan memahami apa yang dirasakan pasien 
Martina Dyah Lestari, Agustina Sri Oktri Hastuti, M. Kep., PhD NS,

Sr. Therese Maura Harjanti CB, MSN

Hubungan Antara Perilaku Caring Perawat Terhadap Kepuasan Pasien Saat Pandemi Covid-19 di Ruang Perawatan Salah Satu Rumah Sakit Swasta di Yogyakarta

dan selau bersedia mendengarkan keluh kesah pasien.

Hasil penelitian ini juga didukung dengan hasil penelitian berjudul "Adaptasi Perilaku Caring Perawat Pada Pasien COVID-19 di Ruang Isolasi”, yang dilakukan oleh Nova, dkk, tahun 2020. Kesimpulan dari penelitian tersebut adalah perawat tetap memiliki perilaku caring dalam memberikan asuhan keperawatan dan dapat beradaptasi menerapkan perilaku caring terhadap pasien COVID-19 dengan ikhlas meskipun sebagai individu mereka memiliki rasa kekhawatiran.

Tabel 6

Tingkat Kepuasan Responden di Ruang Rawat Inap Salah Satu RS Januari-Februari 2021

\begin{tabular}{lcc}
\multicolumn{3}{c}{$(\mathrm{n}-37)$} \\
\hline \multicolumn{1}{c}{ Kategori } & Frekuensi & Presentase \\
\hline $\begin{array}{l}\text { Kurang } \\
\text { Puas }\end{array}$ & 1 & 2.7 \\
\hline Puas & 20 & 54.1 \\
\hline $\begin{array}{l}\text { Sangat } \\
\text { Puas }\end{array}$ & 16 & 43.2 \\
\hline Total & 37 & 100.0 \\
\hline
\end{tabular}

Sumber: Data primer, 2021

Dari hasil penelitian menunjukkan bahwa mayoritas pasien merasa puas dengan pelayanan keperawatan yang diberikan. namun masih terdapat pasien yang kurang puas terhadap pelayanan perawat. Ketidakpuasan satu orang pasien tersebut karena pasien merasa perawat sering bertanya tentang keadaan pasien, tapi tidak melakukan tindakan, jarang menjelaskan tentang hasil pemeriksaan secara rinci kepada pasien, pasien jarang membicarakan masalah pribadi dengan perawat, pasien merasa kadang-kadang perawat tidak teliti dalam melakukan tindakan. Namun demikian, mayoritas pasien di ruang rawat inap tempat dilakukannya penelitian merasa puas dengan pelayanan keperawatan. Komunikasi perawat, baik itu komunikasi langsung maupun komunikasi tidak langsung, dapat dilakukan dengan baik oleh perawat, perhatian kepada pasien, mendengarkan keluhan-keluhan pasien, dan rasa sensitif kepada pasien menjadi nilai lebih bagi perawat. Hal ini sesuai dengan survei kepuasan yang sudah dilakukan oleh salah satu Rumah Sakit swasta di Yogyakarta, bahwa pasien merasa puas dengan pelayanan keperawatan di ruang rawat inap tempat dilakukannya penelitian.

Hal ini sejalan dengan hasil penelitian yang dilakukan oleh Gurusinaga, tahun 2013 tentang kepuasan pasien menggunakan uji Fisher. Hasil penelitian pada kepuasan 
pasien didapatkan bahwa pasien yang merasa sangat puas $(15,4 \%)$, puas $(45,6 \%)$, tidak puas $(38,3)$, dan sangat tidak puas $(0,7 \%)$. Hal tersebut menunjukkan bahwa mayoritas responden menyatakan bahwa sudah merasa puas ketika perawat melakukan praktik profesional.

Tabel 7

Hubungan Perilaku Caring Perawat

Dengan Tingkat Kepuasan Pasien di Ruang Rawat Inap Januari-Februari 2021

\begin{tabular}{llcc}
\hline \multirow{2}{*}{$\begin{array}{l}\text { Perilaku } \\
\text { Caring }\end{array}$} & $\begin{array}{l}\text { Correlation } \\
\text { Coefficient }\end{array}$ & 1.000 & $.437^{* *}$ \\
\cline { 2 - 4 } & $N$ & 37 & 37 \\
\cline { 2 - 4 } & Sig. (2-tailed) &. & .007 \\
\hline \multirow{2}{*}{$\begin{array}{l}\text { Tingkat } \\
\text { Kepuasan }\end{array}$} & $\begin{array}{l}\text { Correlation } \\
\text { Coefficient }\end{array}$ & $.437^{* *}$ & 1.000 \\
\cline { 2 - 4 } & $N$ & 37 & 37 \\
\cline { 2 - 4 } & Sig. (2-tailed) & .007 & \\
\hline
\end{tabular}

**. Correlation is significant at the 0.01 level (2-tailed).

Sumber: Data primer, 2021.

Berdasarkan hasil uji spearman rho didapatkan nilai Sig. (2-tailed) 0,007 ini $<0,05$ sehingga Ho ditolak dan $\mathrm{H} \alpha$ di terima. Artinya ada hubungan yang signifikan antara perilaku caring perawat dengan tingkat kepuasan pasien. nilai correlation coefficient positif, yang menunjukkan terdapat hubungan yang kuat antara perilaku caring perawat dengan tingkat kepuasan pasien. Arah korelasi positif menunjukkan bahwa semakin tinggi perilaku caring perawat, maka kepuasan pasien pada pelayanan keperawatan juga akan semakin tinggi. Perawat adalah orang yang akan berada disamping pasien selama 24 jam. Sehinga Perilaku caring perawat sangat penting dalam memenuhi kepuasan pasien, dan menjadi salah satu indikator mutu rumah sakit. Caring merupakan dasar dalam melaksanakan praktek keperawatan profesional untuk meningkatkan mutu pelayanan keperawatan yang dapat memberikan kepuasan pada klien dan keluarga (Kusnanto, 2019)

Hasil penelitian ini sejalan dengan penelitian yang dilakukan oleh Gurusinaga dkk (2013) di Rumah Sakit Grand Medistra Lubuk Pakamya yang menyimpulkan bahwa ada korelasi antara perilaku caring perawat dengan kepuasan pasien rawat inap dengan $r=$ $0,615$ ( $\mathrm{p}<0,05)$. Sejalan dengan penelitian Mailani dan Fitri di RSUD. DR. Rasidin Padang dimana nilai $\mathrm{P}$ value 0,002 , terdapat hubungan bermakna antara perilaku caring perawat dengan tingkat kepuasan pada pasien BPJS.

Perilaku caring perawat selain sangat penting dalam memenuhi 
Martina Dyah Lestari, Agustina Sri Oktri Hastuti, M. Kep., PhD NS, Sr. Therese Maura Harjanti CB, MSN Hubungan Antara Perilaku Caring Perawat Terhadap Kepuasan Pasien Saat Pandemi Covid-19 di Ruang Perawatan Salah Satu Rumah Sakit Swasta di Yogyakarta

kepuasan pasien, juga merupakan salah satu indikator kualitas pelayanan di sebuah rumah sakit, dilakukan dengan cara pendekatan yang dinamis, dimana perawat bekerja untuk lebih meningkatkan kepeduliannya terhadap pasien. Salah satu kunci dalam memenuhi kepuasan pasien adalah perawat. Oleh karena itu, perilaku caring perawat dapat memberikan pengaruh dalam pelayanan yang berkualitas kepada pasien (Prompahakul, Nilmanat, \& Kongsuwan, 2011 dalam Gurusinaga, 2013).

\section{KESIMPULAN DAN SARAN}

\section{Kesimpulan}

1. Berdasarkan hasil uji spearman rho didapatkan nilai Sig. (2-tailed) 0,007 ini $<0,05$ sehingga Ho ditolak dan $\mathrm{H} \alpha$ di terima. Artinya ada hubungan yang signifikan antara perilaku caring perawat dengan tingkat kepuasan pasien.

2. Nilai Correlation Coefficient 0.437, yang menunjukkan terdapat hubungan yang kuat antara perilaku caring perawat dengan tingkat kepuasan pasien.

3. Arah korelasi positif menunjukkan bahwa semakin tinggi perilaku caring perawat, maka kepuasan pasien pada pelayanan keperawatan juga akan semakin tinggi.

\section{Saran}

1. Semua pihak disarankan untuk terus mendukung semangat caring para perawat dimasa pandemi COVID-19 ini, dengan cara meningkatkan kesehatan fisik, mental dan spiritual perawat sehingga perawat dapat memberikan pelayanan keperawatan dengan profesional dimasa pandemi COVID-19 ini.

2. Perawat perlu meningkatan pengetahuan, mempertahankan sikap caring dan keterampilan professional ketika menjalankan perannya sebagai pemberi asuhan keperawatan, agar dapat menjadi role model, terutama bagi perawat muda/baru.

\section{DAFTAR PUSTAKA}

Gurusinaga, R. (2013). Hubungan perilaku caring perawat dan kepuasan pasien rawat inap $R S$ Adam Malik Medan tahun 2015. [Tesis]. Universitas Sumatera Utara Gurusinga, R., Sulistyaningsih, W, \& Tarigan, M. (2013). Perilaku caring perawat dan kepuasan pasien rawat inap. Jurnal Riset Keperawatan 
Jurnal Keperawatan I CARE, Vol. 2 No. 2 Tahun 2021

Indonesia, (1) 150-155.

https://pantirapih.or.id/rspr/rawat-inap/

diakses 19 Januari 2021

Indrayani, \& Ronoatmodjo, S. (2018).

Faktor-faktor yang Berhubungan

Dengan Kualitas Hidup Lansia di

Desa Cipasung Kabupaten

Kuningan Tahun 2017. Jurnal

Kesehatan Reproduksi, 9(1), 69-78.

Kementrian Kesehatan RI. (2020).

Pedoman Pencegahan dan

Pengendalian Coronavirus Disease

(COVID-19). Jakarta: Kementrian

Kesehatan RI.

Kementrian Kesehatan RI. (2020).

Pedoman Pencegahan dan

Pengendalian Coronavirus Disease

(COVID-19). Jakarta: Kementrian

Kesehatan RI.

Kementrian Dalam Negeri. (2020).

Pedoman Umum Menghadapi

Pandemi COVID-19 Bagi

pemerintah Daerah Pencegahan,

Pengendalian, Diagnosis dan

Manajemen. Jakarta: kementrian

Dalam Negeri.

Kusnanto, (2019) Perilaku Caring

Perawat Professional. Surabaya:

Pusat Penerbitan dan Percetakan

Universitas Airlangga.

Mailani, F., \& Fitri, N. (2017).
Hubungan Perilaku Caring Perawat

Dengan Tingkat Kepuasan Pasien

BPJS Di RSUD DR. Rasidin Padang.

Journal Endurance 2(2), 203-208.

Nova, Y., Utama, T. A., \& Aprilatutini,

T. (2020). Adaptasi Perilaku Caring Perawat Pada Pasien COVID-19 di Ruang Isolasi. Jurnal Keperawatan Muhammadiyah Bengkulu, Volume 08, Nomor 02, 117-127.

Pohan, I. S. (2013). Jaminan Mutu Pelayanan Kesehatan: Dasar-dasar Pengertian dan Penerapan. Jakarta: Penerbit Buku kedokteran EGC.

Ramdhan, K. M., Buchari, R. A., \& Sunija, D. A. (2019). Potret Lanjutan Sekolah: Analisis dampak Rencana Penetapan Wilayah Garyt Utara Sebagai Kawasan Industri. Sosiohumaniora - Jurnal Ilmu-ilmu Sosial dan Humaniora Vol. 21, No. $1,107-112$.

RS Panti Rapih. (2018). Profil Rumah Sakit Panti Rapih Dan Standar Pelayanan Frontliner. Yogyakarta: RS Panti Rapih.

Umam, C., Muchlisoh, L., \& Maryati, H. (2019). Analisis kepuasan pasien terhadap mutu pelayanan kesehatan rawat jalan dengan metode IPA (Importance Perfomance Analysis) 
Martina Dyah Lestari, Agustina Sri Oktri Hastuti, M. Kep., PhD NS, Sr. Therese Maura Harjanti CB, MSN Hubungan Antara Perilaku Caring Perawat Terhadap Kepuasan Pasien Saat Pandemi Covid-19 di Ruang Perawatan Salah Satu Rumah Sakit Swasta di Yogyakarta

di puskesmas Bogor Tengah Kota Bogor tahun 2018. Promotor Jurnal Mahasiswa Kesehatan Masyarakat, 2(1), 7-19
Watson, J. (2009). Assessing and Measuring Caring in Nursing and Health Sciences. New York: Springer Publishing Company, LLC 